\title{
Occurrence of mycotoxin patulin and polyphenol profile of Nordic apple juices in relation to apple cultivation system and pre- processing storage temperature
}

\author{
Lagle Heinmaa ${ }^{1}$, Priit Põldma ${ }^{1}$, Seyed Mahyar Mirmajlessi ${ }^{2}$, Hedi Kaldmäe ${ }^{3}$, Eivind Vangdal ${ }^{4}$, Ulla Kidmose ${ }^{5}$, \\ Marianne Bertelsen ${ }^{5}$, Roberto Lo Scalzo ${ }^{6}$, Marta Fibiani ${ }^{6}$ and Ulvi Moor ${ }^{1}$ \\ ${ }^{1}$ Chair of Horticulture, Institute of Agricultural and Environmental Sciences, Estonian University of Life Sciences, Kreutzwaldi 1, \\ 51006 Tartu, Estonia \\ ${ }^{2}$ Department of Plants and Crops, Ghent University, Coupure links 653, B-9000 Gent, Belgium \\ ${ }^{3}$ Institute of Agricultural and Environmental Sciences Polli, Horticultural Research Centre, Estonian University of Life Sciences, \\ Polli, 69108 Mulgi parish, Viljandi county, Estonia \\ ${ }^{4}$ Division of Biotechnology and Plant Health, NIBIO Ullensvang, NO-5781 Lofthus, Norway \\ ${ }^{5}$ Department of Food Science, Aarhus University, Kirstinebjergvej 10, 5792 Årslev, Denmark \\ ${ }^{6}$ Council for Agricultural Research and Economics, Research Center of Agro-Industrial and Processing Technologies, \\ (CREA-IAA), via Venezian 26, 20133 Milan, Italy \\ e-mail: lagle.heinmaa@student.emu.ee
}

\begin{abstract}
The aims of this study were to find out if organic apple juice (AJ) contained higher contents of polyphenols or patulin compared to conventional $\mathrm{AJ}$, and if higher storage temperature before processing increases patulin content in juice. AJ was pressed from Estonian, Danish and Norwegian apples. Additionally, three cultivars from Estonian organic and conventional orchards were stored at $3 \pm 2{ }^{\circ} \mathrm{C}$ and $9 \pm 2{ }^{\circ} \mathrm{C}$ before processing. Patulin, polyphenol content and antioxidant capacity were determined in pasteurized juices. In $2015,33 \%$ of conventional $(n=6)$ and $46 \%$ of organic $(n=11)$ juices contained patulin; two of the organic juices above the legal limit $\left(191\right.$ and $\left.64 \mu \mathrm{g} \mathrm{I}^{-1}\right)$. In 2016, none of the AJs contained patulin. Patulin occurrence was more affected by weather conditions two weeks before harvest than by cultivation system and apple storage temperature. Polyphenol content was higher in organic than in conventional juices and was reduced at higher apple storage temperature.
\end{abstract}

Key words: organic foods, food safety, Penicillium expansum, chlorogenic acid, catechin, epicatechin

\section{Introduction}

It is widely known that consuming apple and its products has a beneficial health effect - besides their content of vitamins and minerals, they are considered to be a good source of polyphenols with antioxidant activity that scavenge and neutralize free radicals, which in turn play a role in the onset of cardiovascular diseases and cancers (van der Sluis et al. 2002, Biedrzycka and Amarowicz 2008). Polyphenols also make an important contribution to apple juice flavour and colour (Lea and Arnold 1978, Renard et al. 2011).

The worldwide contamination of foods and feeds with mycotoxins such as patulin originating from infected apples is a significant problem. Mycotoxins are secondary metabolites of fungi that account for huge annual losses worldwide in human health, animal health and condemned agricultural products (Zain 2011). Several species of genera Fusarium, Aspergillus, Penicillium and Alternaria can synthesize mycotoxins. These compounds are hazardous to animal and human health as they can be lethal, carcinogenic, mutagenic, teratogenic, immunosuppressant, or may mimic estrogens (Da Cruz Cabral et al. 2013). A mycotoxin found especially in apples and their processed products like juice and puree, is called patulin and it is mainly produced by Penicillium expansum Link - a fungus that causes blue mould rot. The European Commission (EC 2006) set the maximum toxicologically acceptable level for patulin in apple juice to $50 \mu \mathrm{g} \mathrm{I}^{-1}$.

P. expansum is a necrotrophic fungus that requires a wound in the epidermis to infect the fruit (Spotts et al. 1998, Vilanova et al. 2014), therefore it is crucially important to avoid mechanical damage to apples during harvesting and postharvest handling. Patulin has also been stated to be produced by Aspergillus, Byssochlamus, Fusarium, Alternaria and Mucor species (Steiman et al. 1989, Okeke et al. 1993, Laidou et al. 2001, Piqué et al. 2013). However, Frisvad et al. (2006) argued with statements claiming that patulin producers can also be Alternaria alternata, Fusarium culmorum, Mucor hiemalis and Trichothecium roseum. 
The growth of patulin-producing fungi depends on a wide range of factors including water activity, temperature, pH, cultivation method and harvest maturity (da Cruz Cabral et al. 2013, Vilanova et al. 2014). Patulin is heat resistant, especially in acidic environments (Cunha et al. 2014) and therefore apple juice and other pasteurized products pressed from patulin containing apples also contain patulin.

One of the important factors determining fungal growth and mycotoxin production is storage temperature of apples. However, so far there is no consensus whether higher than optimal storage temperature will promote patulin production or not. Baert et al. (2007) reported that patulin concentrations in apples stored at $4{ }^{\circ} \mathrm{C}$ were significantly higher than when stored at $1{ }^{\circ} \mathrm{C}, 7^{\circ} \mathrm{C}$ and $10^{\circ} \mathrm{C}$. It has been found that the highest growth rates occurred in vivo at temperatures between $10{ }^{\circ} \mathrm{C}$ and $25^{\circ} \mathrm{C}$ for Penicillium species (Lahlali et al. 2005). Several small-scale organic apple farmers in Estonia do not have forced air cooling facilities and are using room cooling of apples before processing the juice, which often means that the storage temperature is about $10^{\circ} \mathrm{C}$ depending on autumn weather conditions. Moreover, apples are mostly transported from one country to another in non-refrigerated trucks.

Consumption of organic foods has become increasingly popular, although the safety of organic foods is still unclear and needs to be thoroughly evaluated (Piqué et al. 2013). In conventional apple production, diseases like blue mould rot are avoided by application of fungicides, but this is prohibited in organic production. Some studies have shown higher concentrations of patulin in organic apple products compared to conventional ones (Tournas and Memon 2009, Piqué et al. 2013). In contrast, it has been proposed that in organic production apples are able to create a natural barrier against the attack of pathogens by increased synthesis of phenolic compounds (Wojdyło et al. 2010) and that higher levels of phenolic compounds reduces fungal growth in fruits (Ahmadi-Afzadi et al. 2015).

The present study had two aims: 1 ) to determine the effect of storage temperature higher than optimal before processing on patulin content in apple juice; 2 ) to compare the polyphenols and patulin contents in organic and conventional juices pressed from the same cultivars.

\section{Materials and methods}

\section{Apple origin, cultivars and storage conditions}

In 2015 second grade organic and conventional 'Krameri tuviõun', 'Talvenauding', 'Krista' and organic 'Cortland' apples from Estonia; organic 'Rubinstep', 'Aroma' and 'Ahrista' from Denmark and organic 'Discovery', 'Aroma' and 'Karen Schneider' from Norway were used for juice processing. Estonian apples were harvested from two orchards: 'Krameri tuviõun' and 'Talvenauding' from Vasula, Tartu county ( $\left.58^{\circ} 27^{\prime} 55^{\prime \prime} \mathrm{N} 26^{\circ} 43^{\prime} 00^{\prime \prime} \mathrm{E}\right)$; and 'Cortland' and 'Krista' from Polli, Viljandi county $\left(58^{\circ} 08^{\prime} 05^{\prime \prime} \mathrm{N} 25^{\circ} 32^{\prime} 40^{\prime \prime} \mathrm{E}\right)$. Danish apples were harvested from Årslev $\left(55^{\circ} 18^{\prime} 50^{\prime \prime} \mathrm{N}\right.$ $\left.10^{\circ} 26^{\prime} 40^{\prime \prime} \mathrm{E}\right)$, Norwegian 'Discovery' and 'Aroma' from Sogn (60 $\left.54^{\prime} 46^{\prime \prime} \mathrm{N} 7^{\circ} 11^{\prime} 36^{\prime \prime} \mathrm{E}\right)$ and 'Karen Schneider' from Lofthus $\left(60^{\circ} 19^{\prime} 13^{\prime \prime} \mathrm{N} \mathrm{6} 39^{\prime} 13^{\prime \prime} \mathrm{E}\right)$.

In 2016 organic and conventional 'Liivi kuldrenett', 'Krameri tuviõun', 'Talvenauding' apples from Estonia (Vasula); organic 'Ahrista' and 'Aroma' apples from Denmark (Årslev), organic and conventional 'Discovery' from Norway (Jåstad (60'20'36" N 6³7'16"E) and 'Aroma' from Norway, Lofthus were used. Organic and conventional orchards were located in close proximity to one another, in order to exclude possible pedoclimatic influences on the measured variables. Since second grade apples from organic orchards have large biological variation, $100 \mathrm{~kg}$ of fruits from each cultivar, cultivation technology and storage temperature treatment were pressed into juice in order to ensure that the samples would be representative.

In 2015, a separate experiment with organic and conventional 'Krameri tuviõun', 'Krista' and 'Talvenauding' from Estonia was set up: to determine the effect of storage temperature on apple juice quality, $100 \mathrm{~kg}$ of apples from each cultivar and cultivation technology was stored at $3 \pm 2{ }^{\circ} \mathrm{C}$ and at $9 \pm 2{ }^{\circ} \mathrm{C}$ ('Krameri tuviõun' for 60 , 'Krista' for 73 and 'Talvenauding' for 54 days before pressing). Other Estonian apples and apples from Denmark and Norway were stored at $3 \pm 2{ }^{\circ} \mathrm{C}$. Foreign apples were transported to Estonia by land using a non-refrigerated truck, which took three days from Denmark and five days from Norway. Apples were processed into juice after starch degradation had occurred. 


\section{Juice processing}

Before processing, all apples with visible symptoms of fungal infection were eliminated. Apples were washed, milled with Voran centrifuge RM2.2 (Voran Maschinen GmbH, Pichl bei Wels, Austria) and pressed with waterpress Lancman VSPX 120 (Gomark d.o.o., Vransko, Slovenia). Juices were pasteurized at $85^{\circ} \mathrm{C}$ for 1 min by tubular system and immediately packed into airtight 1.4-litre aluminium foil bags with Bag-in-box filler BBF6 (Gebhardt Anlagentechnik GmbH \& Co. KG, Germany). No enzymatic treatment, centrifugation or ascorbic acid addition were used. Juices were cooled down and preserved in a cool room at $6-10{ }^{\circ} \mathrm{C}$ for up to three months until analyses.

\section{Detection of fungal species contaminating apple cores}

In 2015 all apples with visible symptoms of fungal infection were eliminated, but no detection of fungal species was carried out. In 2016, $20 \mathrm{~kg}$ of apples from each treatment were cut in half, examined for internal symptoms of fungal growth and the percentage of apples with infected cores was calculated. Pieces from each fruit with internal mould symptoms were separately plated onto potato dextrose agar (PDA) in $9 \mathrm{~cm}$ diameter sterile Petri dishes. All plates were incubated at $23 \pm 2{ }^{\circ} \mathrm{C}$ in the dark as previously described by Soliman et al. (2015). Observations of fungal growth were recorded at 7 and 14 days of incubation. Spores were examined under the microscope and fungal species identified by morphological characteristics.

\section{Determination of polyphenols, antioxidant capacity and patulin}

The separation and quantitation of polyphenols were performed on the column SHIM-Pack XR-ODSII, on the UHPLC Shimadzu Nexera X2 system encoupled with mass spectrometer LCMS 8040 with an electrospray (ESI) ionization source (Shimadzu Scientific Instruments, Kyoto, Japan). Quantitation was done using the molecular ions ([M+H]+) in selected reaction monitoring mode. Calibration was done using standard solutions of reference compounds as described by Raudsepp et al. 2010. Chlorogenic acid, epicatechin, catechin, phloridzin, procyanidin B2 and quercitrin were quantitatively determined as previously described by Heinmaa et al. (2017).

For total antioxidant capacity measurements, 1.1-diphenyl-2-picrylhydrazil (DPPH·) radical quenching was used, following the method proposed by Picchi et al. (2012). All measurements were made using an EPR MiniScope MS200 Magnettech (Berlin, Germany). The experimental settings of the spectrometer were as follows: field set, 3,350 G; scan range, $68 \mathrm{G}$; scan time, $30 \mathrm{~s}$; modulation amplitude, 3,000 mG; microwave attenuation, $4 \mathrm{~dB}$; and receiver gain, $1 \times 10^{2}$. EPR spectra were recorded after $1 \mathrm{~min}$ of reaction at $20^{\circ} \mathrm{C}$. The apple juice extracts were made as in a previous work by Heinmaa et al. (2017). The calibration was made with Trolox solutions.

Patulin analyses were carried out at the Estonian Health Board laboratory, which is accredited by the Estonian Accreditation Centre. An in-house method was used based on AFFINISEP Application notebook method (AFFINISEP 2019): juices were pre-treated with pectinase enzyme, the sample preparation was based on Solid Phase Extraction, patulin was eluated from the cartridge with ethyl acetate. After evaporation of the solvent the residue was dissolved in mobile phase and patulin was quantitatively determined by HPLC with UV detection. Minimum level of quantification was $4 \mu \mathrm{g} \mathrm{I}^{-1}$.

\section{Statistical analyses}

All measurements were carried out on three parallel samples for each variable and data were expressed in figures as the mean value \pm standard error (SE). The data were evaluated by one- and two-way analysis of variance (ANOVA) and the means were compared by a Fisher least significant difference (LSD) test at a $5 \%$ probability level. Principal component analysis (PCA) was performed to describe the structure of all the analysed parameters in relation to the cultivar and organic and conventional cultivation system. All analyses were performed using Dell Statistica version 13.0 (Dell Inc., Tulsa, OK, USA).

\section{Results}

\section{The effect of apple storage temperature and cultivation system on patulin concentration in apple juices}

Higher than optimal storage temperature did not a have uniform effect on all cultivars. Juices pressed from both organic and conventional 'Talvenauding' stored at $9 \pm 2{ }^{\circ} \mathrm{C}$ had patulin contamination ( 28 and $5 \mu \mathrm{g} \mathrm{I}^{-1}$ respectively), but juice pressed from the same apples stored at $3 \pm 2{ }^{\circ} \mathrm{C}$ did not have a patulin content above the quantification limit (Table 1). Also, juice from organic 'Krameri tuviõun' apples stored at $9 \pm 2{ }^{\circ} \mathrm{C}$ had patulin content of $8 \mu \mathrm{g} \mathrm{l} \mathrm{l}^{-1}$, while the juice pressed from apples stored at $3 \pm 2{ }^{\circ} \mathrm{C}$ did not contain patulin. In contrast, juice pressed from con- 
ventional 'Krameri tuviõun' apples stored at $9 \pm 2{ }^{\circ} \mathrm{C}$ did not contain patulin, while juice pressed from conventional 'Krameri tuviõun' apples stored at $3 \pm 2{ }^{\circ} \mathrm{C}$ had patulin contamination of $25 \mu \mathrm{gl}^{-1}$. Neither of the juices pressed from 'Krista' apples stored at a warmer temperature contained patulin, whereas juice made of organic apples stored at $3 \pm 2{ }^{\circ} \mathrm{C}$ had low patulin content $\left(6 \mu \mathrm{g} \mathrm{I}^{-1}\right)$.

Among all analysed juices in $2015,46 \%$ of organic $A J(n=11)$ and $33 \%$ of conventional $A J(n=6)$ contained patulin (Table 1). Two organic juices contained patulin above the legal limit: 'Ahrista' juice $191 \mathrm{\mu g} \mathrm{l}^{-1}$ and 'Discovery' juice $64 \mu \mathrm{g} \mathrm{I}^{-1}$.

Table 1. Patulin content $\left(\mu \mathrm{g} \mathrm{l}^{-1}\right) \pm \mathrm{SE}$ in apple juices in 2015 from Estonia (EST), Denmark (DK) and Norway (NO), as affected by organic and conventional cultivation system and pre-processing storage temperature of apples. Total number of analysed juices: 17 in three replications

\begin{tabular}{|c|c|c|c|c|}
\hline \multirow[t]{2}{*}{ Cultivar and country of origin } & \multirow[t]{2}{*}{$\begin{array}{c}\text { Storage } \\
\text { temperature, } \\
{ }^{\circ} \mathrm{C} \pm 2{ }^{\circ} \mathrm{C}\end{array}$} & \multirow[t]{2}{*}{$\begin{array}{l}\text { Storage time, } \\
\text { days }\end{array}$} & \multicolumn{2}{|c|}{$\begin{array}{l}\text { Patulin content in juice, } \\
\qquad \mathrm{g} \mathrm{g}^{-1}\end{array}$} \\
\hline & & & Organic & Conventional \\
\hline 'Talvenauding', EST & 3 & 54 & $<4$ & $<4$ \\
\hline 'Talvenauding', EST & 9 & 54 & $28 \pm 2$ & $5 \pm 0$ \\
\hline ‘Krameri tuviõun', EST & 3 & 60 & $<4$ & $25 \pm 2$ \\
\hline ‘Krameri tuviõun', EST & 9 & 60 & $8 \pm 1$ & $<4$ \\
\hline 'Krista', EST & 3 & 73 & $6 \pm 0$ & $<4$ \\
\hline 'Krista', EST & 9 & 73 & $<4$ & $<4$ \\
\hline 'Ahrista', DK & 3 & 54 & $191 \pm 8$ & no sample \\
\hline 'Rubinstep', DK & 3 & 44 & $<4$ & no sample \\
\hline 'Discovery', NO & 3 & 58 & $64 \pm 5$ & no sample \\
\hline 'Karen Schneider', NO & 3 & 23 & $<4$ & no sample \\
\hline ‘Cortland', EST & 3 & 44 & $<4$ & no sample \\
\hline
\end{tabular}

In 2016, no patulin was found in any of the juices (data not shown) despite the fact that several species of patulin-producing fungi were found from apple cores (Table 2). Organic 'Ahrista' apples had the highest percentage (22.1\%) of apples with visual symptoms of fungal infection in cores. Alternaria spp. was found to be the causal fungal organism after plating spores onto PDA medium. Organic 'Aroma' from Denmark and Norway and organic 'Liivi kuldrenett', 'Krameri tuviõun' and 'Talvenauding' also had some apples with infected cores. Penicillium spp. was found from organic 'Krameri tuviõun' apples and Fusarium spp. from organic 'Talvenauding' apple cores. Conventional apples had almost no signs of fungal infections in the cores; only 'Liivi Kuldrenett' from Estonia had 4.3\% infected cores.

Table 2. The percentage of organic and conventional apples with visual symptoms of pathogen infections in cores before juice processing in 2016 and pathogens determined 7 days after plating spores onto PDA agar

\begin{tabular}{cccccc}
\hline $\begin{array}{c}\text { Cultivar and country of } \\
\text { origin }\end{array}$ & $\begin{array}{c}\text { Storage time } \\
\text { in days }\end{array}$ & \multicolumn{2}{c}{ Percentage of infected cores } & \multicolumn{2}{c}{ Pathogens detected in apple cores } \\
\hline & & Organic & Conventional & Organic & Conventional \\
'Aroma' DK & 54 & 10.6 & no sample & yeast & no sample \\
'Aroma' NO & 60 & 7.2 & None & Penicillium sp. & None \\
'Ahrista' DK & 47 & 22.1 & no sample & Alternaria sp. & no sample \\
& & & & & Penicillium sp. \\
'Discovery' NO & 78 & 3.3 & None & Penicillium sp. & None \\
'Krameri tuviõun' EST & 20 & 3.2 & None & Fusarium sp. & None \\
'Talvenauding' EST & 52 & 1.1 & None & yeast & yeast \\
'Liivi kuldrenett' EST & 19 & 6.7 & 4.3 & &
\end{tabular}




\section{The effect of apple storage temperature and cultivation system on polyphenol concentration in apple juices}

Higher than optimal apple storage temperature had mostly negative effects on juice polyphenol content (Fig. 1). Organic apples tended to be more affected by temperature than conventional ones. For instance, organic 'Krista' juice pressed from apples stored at $9{ }^{\circ} \mathrm{C}$, contained $35 \%$ less epicatechin and $33 \%$ less catechin compared to the juice pressed from apples stored at optimal temperature $\left(3^{\circ} \mathrm{C}\right)$. For conventional 'Krista' juices, higher apple storage temperature caused only a $6 \%$ reduction in epicatechin content and catechin content was not affected. A similar effect was noted for organic and conventional 'Talvenauding' juice catechin and epicatechin content, and for 'Talvenauding' juice procyanidin B2 content. Also, a clear decrease in chlorogenic acid content was detected for organic apples stored at $9{ }^{\circ} \mathrm{C}$, but the same effect was not noticed for conventional apples.
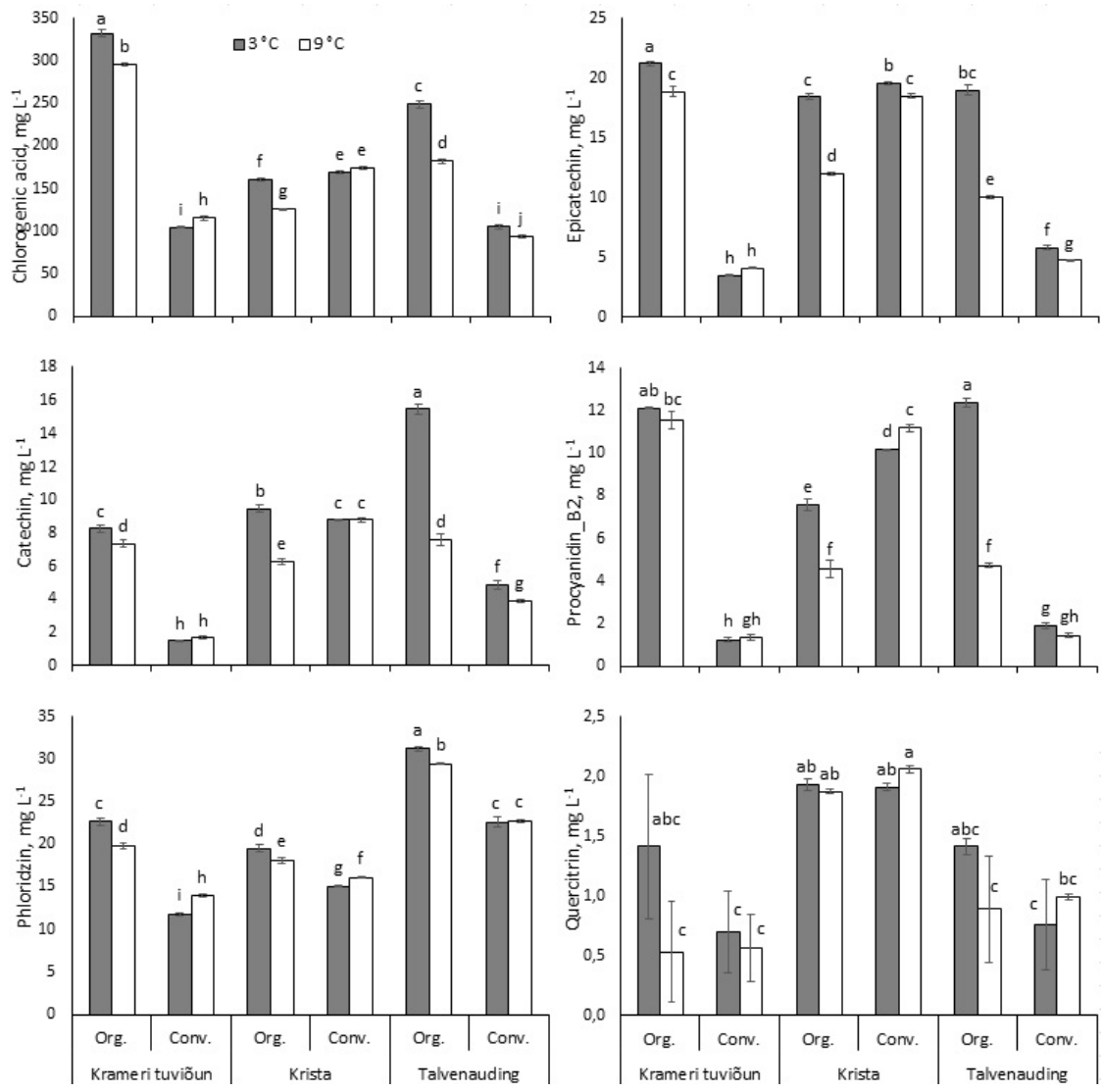

Fig. 1. Concentration of polyphenols in apple juice as affected by apple cultivation system (organic and conventional) and apple storage temperature before processing $\left(3\right.$ and $9 \pm 2{ }^{\circ} \mathrm{C}$ ) in Estonia in 2015. Values are means \pm standard error, $n=3$. Values with different letters are significantly different at $p<0.05$.

The effect of apple cultivation system on juice polyphenol concentration was cultivar-dependent. Significant differences were found in 'Krameri tuviõun' juices in particular, where organic juices contained about three times more chlorogenic acid, four to five times more epicatechin, five times more catechin and about ten times more procyanidin B2 than conventional juices (Fig. 1). This phenomenon was also noted in 2016 (Fig. 2), when organic 'Krameri tuviõun' juice had almost double the amount of chlorogenic acid, three times more epicatechin and more than double the catechin content compared to conventional juices. 'Talvenauding' had also significantly higher contents of chlorogenic acid, epicatechin, catechin and procyanidin B2 in organic juices compared to conventional ones both in 2015 and 2016 (Fig. 1 and 2). Organic 'Aroma' apple juices from Norway had also significantly higher contents of epicatechin, procyanidin B2 and quercitrin compared to conventional ones.

Cultivar differences were also notable (Fig. 2). 'Discovery' juice had significantly higher chlorogenic acid, catechin and procyanidin B2 content compared to juices from other cultivars, with no significant differences between organic and conventional samples. Moreover, 'Aroma' juice had the highest epicatechin content. 'Liivi kuldrenett' had relatively low content of polyphenols compared to juices from other cultivars, except for phloridzin. 

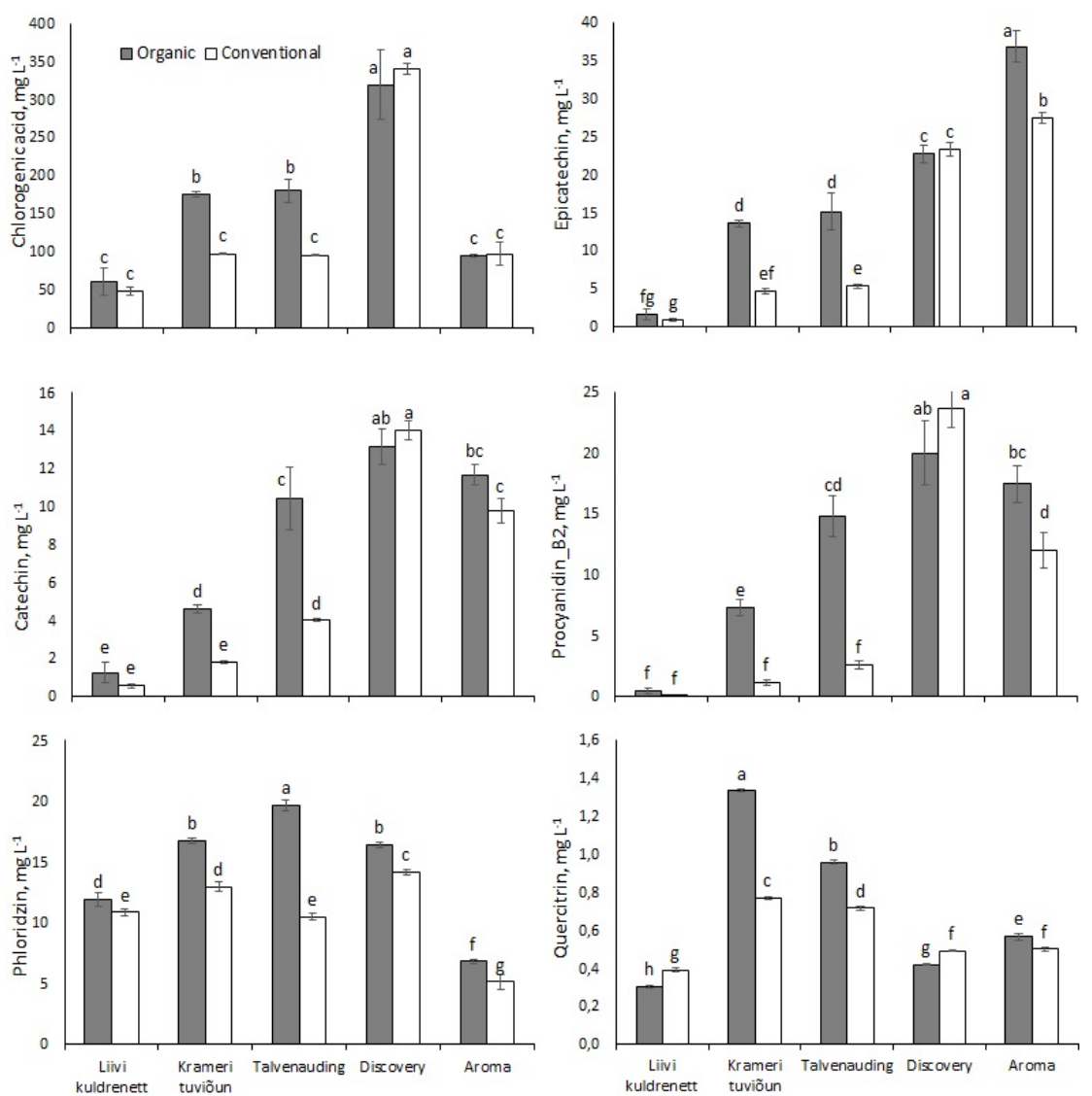

Fig. 2. Concentration of polyphenols in Estonian ('Liivi kuldrenett', 'Krameri tuviõun' and 'Talvenauding') and Norwegian ('Discovery' and 'Aroma') apple juices as affected by apple cultivar and cultivation system (organic and conventional) in 2016. Values are means \pm standard error, $\mathrm{n}=3$. Values with different letters are significantly different at $p<0.05$.

\section{Polyphenols, total antioxidant capacity and patulin content in organic and conventional apple juices as characterized by PCA}

The first two principal components explained $71.6 \%$ of the total variation (Fig. 3A and 3B). The most important determinants of the first principal component (PC1) were procyanidin B2, epicatechin, antioxidant capacity and patulin (Fig. 3A). PC2 was primarily determined by catechin, quercitrin and phloridzin. 'Ahrista' was clearly distinguished in the map (Fig. 3B), situated in the same area with high values of patulin, procyanidin B2 and quercitrin. 'Aroma' 'Discovery' and 'Karen Schneider' formed a group in the same area with catechin. Estonian apples 'Krista', 'Krameri tuviõun' and 'Talvenauding' together with Danish 'Rubinstep' formed a separate group on the opposite side of patulin and polyphenols. Organic and conventional cultivation method did not have clear distinctions in the PCA map.
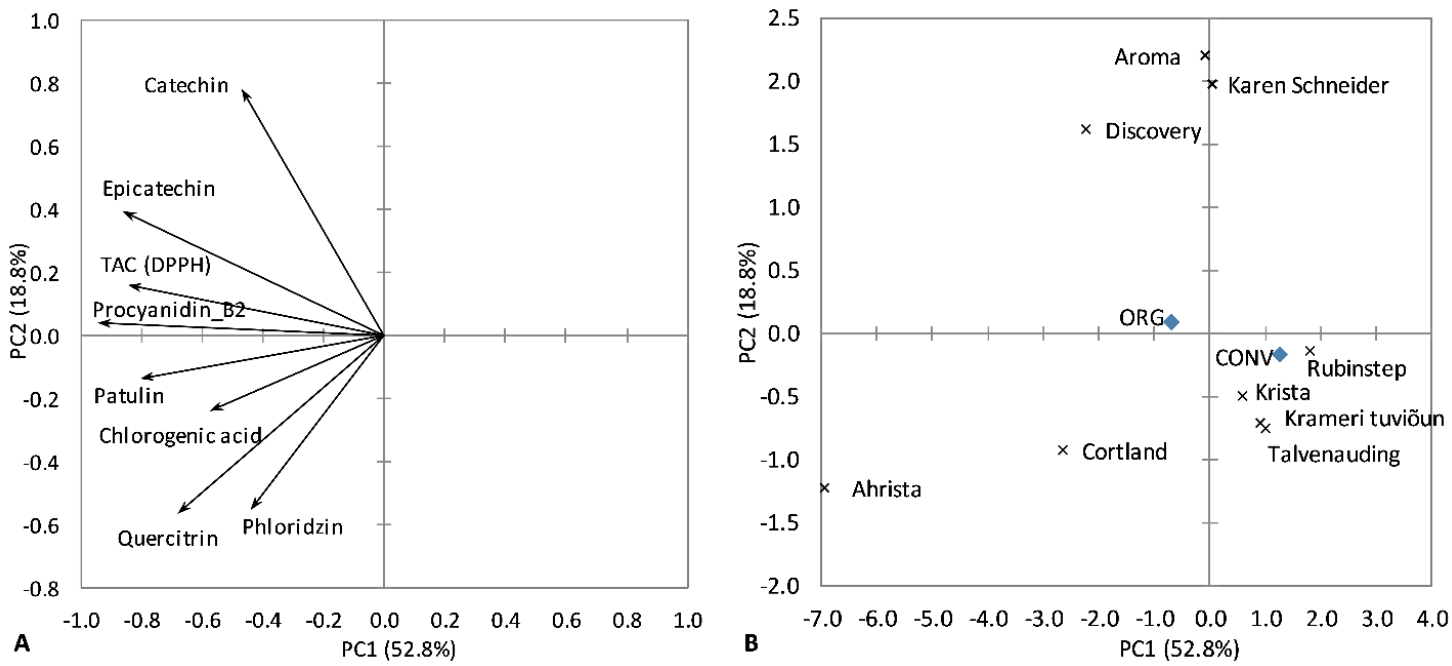

Fig. 3. Principal Component Analysis plots of the first two PC-s. The loading of patulin, antioxidant capacity and all analysed polyphenols are presented on the left (A) and the loading of cultivars and cultivation system on the right (B). 


\section{Discussion \\ Possible reasons for patulin occurrence in apple juices}

In the current experiment, a total of 29 apple juices were analysed for patulin content. Based on the results, patulin formation is affected by multiple factors, among which cultivation system and apple storage temperature before processing might not be the most important ones.

It is common knowledge that apple storage temperature should be as low as possible in order to slow down respiration and inhibit development of postharvest diseases. Tournas and Memon (2009) stated that storage of the fruit at/or below $5^{\circ} \mathrm{C}$ will inhibit the growth of $P$. expansum and prevent the production of patulin. Louw and Korsten (2014) reported that higher temperatures $\left(6.2 \pm 1.7^{\circ} \mathrm{C}\right.$ vs. $\left.0^{\circ} \mathrm{C}\right)$ resulted in a shorter lag phase and faster growth rate for $P$. expansum. Our study indicated that higher storage temperatures will increase the probability for patulin occurrence in cultivars whose fruits have thin and fragile skin, like 'Krameri tuviõun' and 'Talvenauding', but not in firm apples with thicker skin like 'Krista'. As reported by Univer et al. (2009), 'Krista' had significantly higher flesh firmness compared to 'Talvenauding' (76.7 and 49.3N, respectively) 3 months after harvest.

Several studies have claimed that conventional apples have a lower incidence of toxigenic moulds compared to organic apples (Tournas and Memon 2009, Piqué et al. 2013). Other researchers have found that cultivation system did not have any significant effect on patulin content in apples (Cunha et al. 2014). Also, according to largescale surveillance of patulin in apple products in Michigan (Harris 2007), 42.9\% of organic AJs ( $n=14)$ had detectable patulin, whereas only $21.4 \%$ of conventional AJs $(n=145)$ had patulin contamination. Based on our results from the year 2015 , a similar trend was noticed: $46 \%$ of organic apple juices and $33 \%$ of conventional apple juices contained patulin. However, there were exceptions: juice pressed from conventional 'Krameri tuviõun' contained patulin $\left(25 \mathrm{\mu g} \mathrm{l}^{-1}\right)$, whereas its organic counterpart did not contain patulin. One of the hypothetical reasons could be presence of bitter pit in conventional apples, which was probably caused by excessive nitrogen fertilization and intensive pruning of trees in early spring, which was not done in the organic orchard. Even though bitter pit is a physiological disorder, it can weaken the resistance of the fruit to pathogens and necrotic pitted tissue may be a favourable environment for the growth of patulin-producing fungi.

In 2015, juice of organic 'Ahrista' and 'Discovery' had patulin content above the EU legal limit (191 and $64 \mu \mathrm{g} \mathrm{I}^{-1}$, respectively). The result was surprising, since apples were firm and had no visual symptoms of any fungal diseases. Due to the good visual appearance, apple cores were not inspected in 2015. It is known that patulin is mainly produced in rotten parts of the fruits (Cheraghali et al. 2005). Zhong et al. (2018) reported that patulin has been constantly detected in apple products made from externally healthy apples that have internal rot which is not omitted before pressing. However, Soliman et al. (2015) reported that several fungal species may inhabit the core of the fruit that appears visually blemish free. Cracks of the seed cavity may occur due to certain harsh environmental conditions and fungal spores can come in contact with the internal tissue of the fruit using it as a substrate, in this case a sound fruit may contain toxins (Tournas and Memon 2009). Soliman et al. (2015) reported that patulin-producing Penicillium caused a serious problem since the fungus can still grow and produce the mycotoxin without destroying the fruit itself.

In 2016, apples in the current experiment were cut in half prior to processing to inspect the cores. From conventional apples, only Estonian 'Liivi kuldrenett' fruits had visual mould symptoms in the core. The majority of organic apples had insect damage and many of them had visual symptoms of fungal infection in the core. Penicillium spp. was found in organic 'Krameri tuviõun' apples of Estonian origin and in organic 'Aroma' apples originating from Norway. Alternaria spp. was detected in both organic and conventional 'Ahrista' apples, which had been grown in Denmark. Fusarium spp. was detected in conventional 'Ahrista' and organic 'Talvenauding' apple cores.

The highest percentages of apples with visible core mould were found in organic 'Ahrista' and organic 'Aroma' apples from Denmark (22.1\%, $16.2 \%$ and $10.6 \%$, respectively). Named cultivars had patulin in juice the year before, but none of the apple juices were contaminated with patulin in 2016. The hypothesis was formulated that the patulin formation in 2015 could be related to differences in weather conditions in 2015 and 2016. Spotts et al. (2009) have stated that rainfall during or just before harvest may increase the risk of post-harvest decay; therefore the sum of precipitation and average temperature two weeks before harvest of each apple cultivar was analysed. It was revealed that in Danish and Estonian orchard locations, the harvest season in 2016 was a lot drier and warmer compared to the 2015 season when patulin was found in juice (Table 3). For instance, in 2015 the temperature and rainfall two weeks before harvest of 'Ahrista' apples was average for this period, but in 2016 
there was almost no rain $(1.5 \mathrm{~mm})$. In the location of 'Aroma' there was $22 \mathrm{~mm}$ more rain in 2015 and in the location of 'Krameri tuviõun' 16 mm more rain fell in 2015, compared to 2016 during the two weeks before harvest. Norwegian 'Discovery' was an exception, since it rained more in 2016 and the reasons for patulin occurrence in juice in 2015 remain unclear.

Table 3. Patulin content in juice pressed from Estonian, Danish and Norwegian apples in 2015 and 2016 in relation to average temperature $\left({ }^{\circ} \mathrm{C}\right)$ and sum of precipitation $(\mathrm{mm})$ during the two weeks prior harvest, and compared to the 36 year-average (19802016) for the same period.

\begin{tabular}{|c|c|c|c|c|c|c|c|c|}
\hline Cultivar & $\begin{array}{l}\text { Location of } \\
\text { the orchard }\end{array}$ & $\begin{array}{c}\text { Culti- } \\
\text { vation } \\
\text { system }\end{array}$ & $\begin{array}{l}\text { Date of } \\
\text { harvest }\end{array}$ & $\begin{array}{l}\text { Av. temp. } \\
\text { two } \\
\text { weeks } \\
\text { prior } \\
\text { harvest }\end{array}$ & $\begin{array}{l}\text { Sum of precipi- } \\
\text { tation two } \\
\text { weeks prior to } \\
\text { harvest }\end{array}$ & $\begin{array}{l}\text { Av. temp. } \\
\text { for the same } \\
\text { two weeks } \\
\text { during } \\
\text { 1980-2016 }\end{array}$ & $\begin{array}{c}\text { Average } \\
\text { precipitation for } \\
\text { the same two } \\
\text { weeks during } \\
\text { 1980-2016 }\end{array}$ & $\begin{array}{l}\text { Patulin } \\
\text { content in } \\
\text { juice } \mu \mathrm{g} \mathrm{I}^{-1} \\
\quad \pm \mathrm{SE}\end{array}$ \\
\hline & & & & 2015 & & & & \\
\hline 'Krameri tuviõun' & EST, Vasula & CONV & $16 \mathrm{Sept}$ & 13.2 & 39.5 & 12.6 & 28.9 & $25 \pm 2$ \\
\hline 'Krameri tuviõun' & EST, Vasula & OR & 12 Sept & 13.6 & 47.8 & 13.3 & 30.7 & $<4$ \\
\hline 'Krista' & EST, Polli & CONV & 09 Sept & 14.9 & 25.4 & 13.8 & 35.4 & $<4$ \\
\hline Krista' & EST, Polli & OR & 09 Sept & 14.9 & 25.4 & 13.8 & 35.4 & $6 \pm 0$ \\
\hline 'Aroma' & DK, Årslev & OR & 15 Sept & 14.1 & 40.2 & 14.6 & 35.8 & $37 \pm 4$ \\
\hline 'Ahrista' & DK, Årslev & OR & 28 Sept & 13.5 & 24.4 & 13.1 & 28.1 & $191 \pm 8$ \\
\hline \multirow[t]{2}{*}{ 'Discovery' } & NOR, Sogn & OR & 23 Sept & 13.6 & 34.7 & 10.2 & 38.6 & $64 \pm 5$ \\
\hline & & & & 2016 & & & & \\
\hline 'Krameri tuviõun’ & EST, Vasula & CONV & 09 Sept & 15.8 & 17.5 & 13.8 & 35.6 & $<4$ \\
\hline 'Krameri tuviõun' & EST, Vasula & OR & 09 Sept & 15.8 & 17.5 & 13.8 & 35.6 & $<4$ \\
\hline 'Aroma' & DK, Årslev & OR & 13 Sept & 17.8 & 24.4 & 14.8 & 33.1 & $<4$ \\
\hline 'Ahrista' & DK, Årslev & OR & 20 Sept & 18.0 & 1.5 & 14.1 & 33 & $<4$ \\
\hline 'Discovery' & NOR, Jåstad & OR & 08 Sept & 13.9 & 85.5 & 12.4 & 63.4 & $<4$ \\
\hline
\end{tabular}

Only those apple cultivars have been included in the table, for which either organic or conventional counterparts had patulin content in juice in 2015. Total number of analysed juices in 2015 and 2016: 29 in three replications.

\section{Factors affecting polyphenol concentration in apple juices}

As reviewed by Kalinowska et al. (2014), the concentration of individual phenolic compounds in apples depends on the cultivar, maturity of the fruit, cultivation conditions, harvest, storage and infections. Phenolic compounds have an important role as defence mechanisms against pathogens and patulin (Cushnie and Lamb 2005, Ferreyra et al. 2012, Sun et al. 2017, Zhong et al. 2018). However, which particular pathogens induce the formation of phenolic compounds, is usually not specified. One reason why juice pressed from organic apples had significantly higher concentrations of polyphenols could be the difference in apple fruit moth (Agryresthia conjugella Zeller) damage. This pest was highly abundant in Vasula organic orchard in Estonia, and 'Talvenauding' and 'Krameri tuviõun' apples originating from this orchard had the largest differences in polyphenols between organic and conventional apple juices (Fig. 1 and 2).

The degrading effect of higher than optimal apple storage temperature on polyphenols and reasons why polyphenol concentration in organic apples decreased more than in conventional ones, could be related to polyphenol oxidase (PPO) activity. As reported by Mizobutsi et al. (2010), the PPO activity was highest at $20{ }^{\circ} \mathrm{C}$. PPO is generally located in plastids of intact cells, while substrates of the enzyme, the polyphenols, are located in the vacuoles. Thus, they come into contact when cells are damaged. As mentioned before, organic apples had multiple injuries caused by pest insects, which could permit enzymes and substrates to come into contact with one another and cause polyphenol degradation. Tsurutani et al. (2002) found that mature apples showed PPO activity in both the plastidal and soluble fractions and concluded that part of the PPO is transported in plastids, and then partly solubilized. Mentioned authors also proved that plastidal PPO showed several times higher activity than the soluble fraction of PPO. This might explain why the degradation of polyphenols in conventional fruits, where plastid-bound PPO could not be in contact with substrate, was less pronounced than in organic apples, where both forms of PPO-s could have activity. 
The negative effect of warmer storage temperature was especially seen on chlorogenic acid, epicatechin and catechin content, which was significantly lower in all organic apples irrespective of cultivar differences. As reported by Fevrier et al. (2017), the apple PPO oxidises specific substrates, mainly caffeoylquinic acid (also called chlorogenic acid), catechins and dihydrochalcones. This supports our theory that degradation of polyphenols is related to PPO activity.

\section{Possible interactions between polyphenols and patulin}

It has been reported that procyanidin B2 has a significant impact on blue mould development with partial resistance to this disease in various commercial apple cultivars (Ahmadi-Afzadi et al. 2015). However, our results do not support this finding. As characterized by PCA, 'Ahrista' juice was clearly distinguished by high procyanidin B2

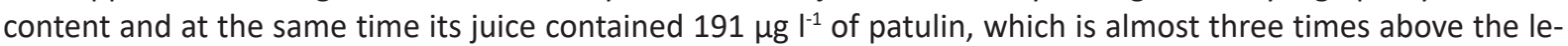
gal limit. Several cultivars having much lower procyanidin B2 contents did not have any patulin in juice. Yin et al. (2017) reported that phloridzin could promote the growth and conidial division of Fusarium moniliforme under the experimental conditions. This is in accordance with our results - organic 'Talvenauding' apple juice had the highest concentration of phloridzin in 2016 and the fungus Fusarium spp. was detected from apple cores in 2016. Lattanzio et al. (2001) reported that the content of total phenols in apples was higher in the peel around the rotten zone than in the healthy peel. We do not argue with this finding, because in our experiment, no apples with visible rotten zones were pressed into juice. However, in our opinion, polyphenol content in apples is cultivar specific and other factors like weather conditions prior to harvest are more likely to affect apple infection and patulin production.

\section{Conclusions}

Mycotoxin patulin contamination of apple juice has been associated with insufficient inspection of fruits before juice processing, when rotten parts of the apples are pressed into juice. Results from this study showed that patulin can also be found in excessive amounts in juice pressed from visually non-spoiled apples. Higher, than optimal storage temperatures may increase the risk for patulin formation in some cultivars, especially in those with thin skin. Moreover, polyphenols in organic apples were more prone to degradation if apples were kept at higher than optimal storage temperatures before juice processing. It was not proven that organic cultivation method would always increase the risk for patulin occurrence in apple juice. More attention should be paid to the yearly fluctuations in weather conditions, especially rainfall two weeks before apple harvest. We suggest that in rainy harvest seasons, apples for juice processing should be more carefully inspected, including inspections of possible moulds in apple cores.

Based on our results, there was a tendency for organic apple juice to contain more polyphenols than conventional juice, but the proposed protective effect of polyphenols against patulin-producing fungi was not confirmed. Some cultivars may have high polyphenol content and excessive amounts of patulin at the same time.

Our study indicated that patulin occurrence in apple juice is affected by multiple factors and further studies with different cultivars in different pre- and postharvest conditions should be carried out, in order to better understand the risk for its occurrence in apple products.

\section{Acknowledgements}

Authors are grateful for Core Organic Plus project FaVOR-DeNonDe and Estonian Ministry of Rural Affairs for funding the research.

\section{References:}

AFFINISEP 2019. AFFINISEP Notebook for sampling and sample preparation: https://www.affinisep.com/media/application_notebook_affinisep_007425700_0954_27012014.pdf. Accessed 21 June 2019.

Ahmadi-Afzadi, M., Nybom, H., Ekholm, A., Tahir, I. \& Rumpunen, K. 2015. Biochemical contents of apple peel and flesh affect level of partial resistance to blue mold. Postharvest Biology and Technology 110: 173-182. https://doi.org/10.1016/j. postharvbio.2015.08.008

Baert, K., Devlieghere, F., Flyps, H., Oosterlinck, M., Ahmed, M.M., Rajković, A., Verlinden, B., Nicolaï, B., Debevere, J. \& de Meulenaer, B. 2007. Influence of storage conditions of apples on growth and patulin production by Penicillium expansum. International Journal of Food Microbiology 119: 170-181. https://doi.org/10.1016/j.ijfoodmicro.2007.07.061 
Biedrzycka, E. \& Amarowicz, R. 2008. Diet and Health: Apple polyphenols as antioxidants. Food Reviews International 24: 235251. https://doi.org/10.1080/87559120801926302

Cheraghali, A.M., Mohammadi, H.R.S., Amirahmadi, M., Yazdanpanah, H., Abouhossain, G., Zamanian, F., Khansari, M.G. \& Afshar M. 2005. Incidence of patulin contamination in apple juice produced in Iran. Food Control 16: 165-167. https://doi.org/10.1016/j. foodcont.2004.01.006

Cunha, S.C., Faria, M.A., Pereira, V.L., Oliveira, T.M., Lima, A.C. \& Pinto, E. 2014. Patulin assessment and fungi identification in organic and conventional fruits and derived products. Food Control 44: 185-190. https://doi.org/10.1016/j.foodcont.2014.03.043

Cushnie, T.P. \& Lamb, A.J. 2005. Antimicrobial activity of flavonoids. International Journal of Antimicrobial Agents 26: 343-356. https://doi.org/10.1016/j.ijantimicag.2005.09.002

da Cruz Cabral, L., Fernández Pinto, V. \& Patriarca, A. 2013. Application of plant derived compounds to control fungal spoilage and mycotoxin production in foods. International Journal of Food Microbiology 166: 1-14. https://doi.org/10.1016/j. ijfoodmicro.2013.05.026

EC 2006. European Commission Regulation (EC) No 1881/2006 of 19 December 2006 setting maximum levels for certain contaminants in foodstuffs. ELI. http://data.europa.eu/eli/reg/2006/1881/2014-07-01. Accessed 27 October 2018.

Ferreyra, M.L.F., Rius, S.P. \& Casati, P. 2012. Flavonoids: biosynthesis, biological functions, and biotechnological applications. Frontiers in Plant Science 3: 1-15. https://doi.org/10.3389/fpls.2012.00222

Fevrier, H., Le Quere, J.-M., Le Bail, G. \& Guyot, S. 2017. Polyphenol profile, PPO activity and pH variation in relation to colour changes in a series of red-fleshed apple juices. LWT-Food Science and Technology 85: 353-362. https://doi.org/10.1016/j.Iwt.2016.11.006

Frisvad, J.C., Nielsen, K.F. \& Samson, R.A. 2006. Recommendations concerning the chronic problem of misidentification of mycotoxigenic fungi associated with foods and feeds. In: Hocking, A.D., Pitt, J.I., Samson, R.A. \& Thrane, U. (eds.). Advances in Food Mycology. New York, USA: Springer. p. 33-46. https://doi.org/10.1007/0-387-28391-9_2

Harris, K.L. 2007. Patulin: surveillance in Michigan apple cider and juice, and factors influencing its production and concentration in apple products. Ph.D thesis. Michigan State University. $172 \mathrm{p}$.

Heinmaa, L., Moor, U., Põldma, P., Raudsepp, P., Kidmaose, U. \& Lo Scalzo, R. 2017. Content of health-beneficial compounds and sensory properties of organic apple juice as affected by processing technology. LWT - Food Science and Technology 85 (B): 372-379. https://doi.org/10.1016/j.Iwt.2016.11.044

Kalinowska, M., Bielawska, A., Lewandowska-Siwkiewicz, H., Priebe, W. \& Lewandowski, W. 2014. Apples: Content of phenolic compounds vs. variety, part of apple and cultivation model, extraction of phenolic compounds, biological properties. Plant Physiology and Biochemistry 84: 169-188. https://doi.org/10.1016/j.plaphy.2014.09.006

Lahlali, R., Serrhini, M.N. \& Jijakli, M.H. 2005. Studying and modelling the combined effect of temperature and water activity on the growth rate of $P$. expansum. International Journal of Food Microbiology 103: 315-322. https://doi.org/10.1016/j. ijfoodmicro.2005.02.002

Laidou, I.A., Thanassoulopoulos, C.C. \& Liakopoulou-Kyriakides, M. 2001. Diffusion of patulin in the flesh of pears inoculated with four postharvest pathogens. Journal of Phytopathology 149: 457-461. https://doi.org/10.1046/j.1439-0434.2001.00663.x

Lattanzio V., Di Venere D., Linsalata V. \& Bertolini, P. 2001. Low temperature metabolism of apple phenolics and quiescence of Phlyctaena vagabunda. Journal of Agricultural and Food Chemistry 49: 5817-5821. https://doi.org/10.1021/jf010255b

Lea, A.G.H. \& Arnold, G.M. 1978. The phenolics of ciders: bitterness and astringency. Journal of the Science of Food and Agriculture 29: 478-483. https://doi.org/10.1002/jsfa.2740290512

Louw, J. \& Korsten, L. 2014. Pathogenic Penicillium spp. on apple and pear. Plant Disease 98: 590-598. https://doi.org/10.1094/ PDIS-07-13-0710-RE

Mizobutsi, G.P., Finger, F.L., Ribeiro R.A., Puschmann, R., de Melo Neves, L.L. \& Ferreira da Mota, W. 2010. Effect of pH and temperature on peroxidase and polyphenoloxidase activities of litchi pericarp. Scientia Agricola (Piracicaba, Braz.) 67: 213-217. https://doi.org/10.1590/S0103-90162010000200013

Okeke, B., Seigle-Murandi, F., Steiman, R., Benoit-Guyod, J. \& Kaouadji, M. 1993. Identification of Mycotoxin-Producing Fungal Strains: A Step in the isolation of compounds active against rice fungal diseases. Journal of Agricultural and Food Chemistry 41: 1731-1735. https://doi.org/10.1021/jf00034a040

Picchi, V., Migliori, C., Lo Scalzo, R., Campanelli, G., Ferrari, V. \& di Cesare, L.F. 2012. Phytochemical content in organic and conventionally grown Italian cauliflower. Food Chemistry 130: 501-509. https://doi.org/10.1016/j.foodchem.2011.07.036

Piqué, E., Vargas-Murga, L., Gómez-Catalán, J., de Lapuente, J. \& Llobet, J.M. 2013. Occurrence of patulin in organic and conventional apple-based food marketed in Catalonia and exposure assessment. Food and Chemical Toxicology 60: 199-204. https:// doi.org/10.1016/j.fct.2013.07.052

Raudsepp, P., Kaldmäe, H., Kikas, A., Libek, A. \& Püssa, T. 2010. Nutritional quality of berries and bioactive compounds in the leaves of black currant (Ribes nigrum L.) cultivars evaluated in Estonia. Journal of Berry Research 1: 53-59.

Renard, C.M.G.C., Le Quéré, J.-M., Bauduin, R., Symoneaux, R., Le Bourvellec, C. \& Baron, A. 2011. Modulating polyphenolic composition and organoleptic properties of apple juices by manipulating the pressing conditions. Food Chemistry 124: 117-125. https://doi.org/10.1016/j.foodchem.2010.05.113

Soliman, S., Li, X.-Z., Shao, S., Behar, M., Svircev, A.M., Tsao, R. \& Zhou, T. 2015. Potential mycotoxin contamination risks of apple products associated with fungal flora of apple core. Food Control 47: 585-591. https://doi.org/10.1016/j.foodcont.2014.07.060

Spotts, R.A., Sanderson, P.G., Lennox, C.L., Sugar, D. \& Cervantes, L.A. 1998. Wounding, wound healing and staining of mature pear fruit. Postharvest Biology and Technology 13: 27-36. https://doi.org/10.1016/S0925-5214(97)00079-3

Spotts, R.A., Serdani, M., Wallis, K.M., Walter, M., Harris-Virgin, T., Spotts, Ki., Sugar, D., Xiao, C.L. \& Qu, A. 2009. At-harvest prediction of grey mould risk in pear fruit in long-term cold storage. Crop Protection $28: 414-420$. https://doi.org/10.1016/j. cropro.2009.01.001 
Steiman, R., Seigle-Murandi, F., Sage, L. \& Krivobok, S. 1989. Production of patulin by Micromycetes. Mycopathologia 105: 12933. https://doi.org/10.1007/BF00437244

Sun, J., Janisiewicz, W.J., Nichols, B., Jurick, W.M. II \& Chen, P. 2017. Composition of phenolic compounds in wild apple with multiple resistance mechanisms against postharvest blue mold decay. Postharvest Biology and Technology 127: 68-75. https://doi. org/10.1016/j.postharvbio.2017.01.006

Tournas, V.H. \& Memon, S.U. 2009. Internal contamination and spoilage of harvested apples by patulin-producing and other toxigenic fungi. International Journal of Food Microbiology 133: 206-209. https://doi.org/10.1016/j.ijfoodmicro.2009.05.025

Tsurutani, M., Yanagida, Y., Hagiwara, S., Murata, M. \& Homma, S. 2002. Comparison of soluble and plastidal polyhenol oxidase in mature apples. Food Science and Technology Research 8: 42-44. https://doi.org/10.3136/fstr.8.42

Univer, N., Univer, T., Bleive. U. \& Tiirmaa, K. 2009. The first research on CA-storage of apples in Estonia. In: Erkan, M. \& Aksoy, U. (eds.). Proceedings of the 10th Controlled \& Modified Atmosphere Research Conference, in April in Antalya, Turkey. ISHS. 48 p.

van der Sluis, A., Dekker, M., Skrede, G. \& Jongen, W. 2002. Activity and concentration of polyphenolic antioxidants in apple juice. 1. effect of existing production methods. Journal of Agricultural and Food Chemistry 50: 7211-7219. https://doi.org/10.1021/ jf020115h

Vilanova, L., Viñas, I., Torres, R., Usall, J., Buron-Moles, G. \& Teixidó, N. 2014. Increasing maturity reduces wound response and lignification processes against Penicillium expansum (pathogen) and Penicillium digitatum (non-host pathogen) infection in apples. Postharvest Biology and Technology 88: 54-60. https://doi.org/10.1016/j.postharvbio.2013.09.009

Wojdyło, A., Oszmiański, J. \& Bielicki, P. 2010. Chemical composition, phenolic compounds and antioxidant activity of three varieties of apple from organic and conventional farming. Journal of Research and Applications in Agricultural Engineering 55: $173-177$.

Yin, C., Xiang, L., Wang, G., Wang, Y., Shen, X., Chen, X. \& Mao, Z. 2017. Phloridzin promotes the growth of Fusarium moniliforme (Fusarium verticillioides). Scientia Horticulturae 214: 187-194. https://doi.org/10.1016/j.scienta.2016.11.035

Zain, M.E. 2011. Impact of mycotoxins on humans and animals. Journal of Saudi Chemical Society 15: 129-144. https://doi. org/10.1016/j.jscs.2010.06.006

Zhong, L., Carere, J., Lu, Z. \& Zhou, T. 2018. Patulin in apples and apple-based food products: the burdens and the mitigation strategies. Toxins 475. https://doi.org/10.3390/toxins10110475 